\title{
Identifikasi Senyawa Bioaktif pada Ekstrak Kelinci Laut (Dolabella auricularia) dan Penghambatannya terhadap Aeromonas hydrophila
}

\author{
[Identification of Bioactive Compounds in Wedge Sea Hare Extract (Dolabella auricularia) \\ Extract and Its Inhibition against Aeromonas hydrophila]
}

\author{
Nurhalisa $^{1 *}$, Wulandari ${ }^{1}$, Indriyani Nur ${ }^{1}$, Suryani $^{2}$, Kadir Sabilu $^{1}$ \\ ${ }^{1}$ Program Studi Budidaya Perairan, Fakultas Perikanan dan Ilmu Kelautan, Universitas Halu Oleo \\ ${ }^{2}$ Program Studi Farmasi, Universitas Halu Oleo \\ JL. HAE Mokodompit Kampus Bumi Tridharma Anduonohu Kendari, Indonesia, 93232 \\ *Email korespondensi: Lnurhalisa27@gmail.com
}

\begin{abstract}
ABSTRAK
Perairan laut di Indonesia kaya akan biota yang dapat dimanfaatkan senyawa aktif yang dikandungnya, salah satunya adalah dari golongan gastropoda jenis kelinci laut (D. auricularia). Penelitian ini bertujuan untuk mengetahui kandungan senyawa dari hasil ekstraksi kelinci laut serta mengkaji kemampuan bahan aktif dalam mengendalikan infeksi bakteri patogen Aeromonas hydrophila melalui pengamatan penghambatannya secara in vitro. Metode penelitian yaitu eksperimen laboratorium dimana proses ekstraksi, skrining bioaktif, dan uji in vitro menggunakan metode maserasi, kalorimetri, dan difusi cakram Kirby-Bauer. Hasil penelitian menunjukan ekstraksi kelinci laut menggunakan pelarut etil asetat dengan rasio bahan dan pelarut yaitu 1:2 menghasilkan rendemen ekstrak sebesar 0,32\% dan mengandung senyawa phenolic, tanin, steroid, terpenoid, alkaloid, dan saponin. Senyawa-senyawa tersebut dapat dimanfaatkan sebagai antibakteri karena pada penelitian ini terbukti mampu menghambat pertumbuhan bakteri A. hydrophila hingga dosis minimum yang diujikan yakni $1000 \mathrm{ppm}$ secara in vitro. Daya hambat terhadap bakteri $A$. hydrophila menunjukan nilai yang tinggi seiring dengan penambahan konsentrasi terutama pada konsentrasi 7000 ppm dibandingkan kontrol. Olehnya ekstrak kelinci laut berpotensi untuk pengembangan penyakit ikan pada akuakultur, khususnya untuk pengendalian penyakit Motile Aeromonas Septicemia (MAS) yang disebabkan oleh bakteri A. hydrophila.
\end{abstract}

Kata kunci: Kelinci laut, Aeromonas hydrophila, in vitro

\section{ABSTRACT}

Marine waters in Indonesia are rich in biota that can be used for the active compounds they contain, one of which is from the gastropod group of wedge sea hare (D. auricularia). This study aims to determine the content of compounds extracted from wedge sea hare and to examine the ability of the active ingredients to control infection with the pathogenic Aeromonas hydrophila by observing its inhibition in vitro. The research method is a laboratory experiment in which the extraction process, bioactive screening, and in vitro test use the Kirby-Bauer disk maceration, calorimetry, and diffusion methods. The results showed that the extraction of wedge sea hare using ethyl acetate solvent with a ratio of 1:2 material and solvent resulted in an extract yield of $0.32 \%$ and contained phenolic compounds, tannins, steroids, terpenoids, alkaloids, and saponins. These compounds can be used as antibacterials because in this study they were proven to be able to inhibit the growth of A. hydrophila up to the minimum tested dose of $1000 \mathrm{ppm}$ in vitro. Inhibition against $A$. hydrophila showed a high value along with the addition of concentration, especially at a concentration of $7000 \mathrm{ppm}$ compared to control. Therefore, wedge sea hare extract has the potential to develop fish diseases in aquaculture, especially for controlling Motile Aeromonas Septicemia (MAS) caused by A. hydrophila.

Keywords: Wedge Sea Hare, Aeromonas hydrophila, in vitro

\section{PENDAHULUAN}

Masalah penyakit pada ikan merupakan salah satu kendala utama yang dihadapi oleh pembudidaya karena berpotensi menimbulkan kerugian yang sangat besar seperti penurunan hasil produksi dan bahkan kematian masal pada ikan. Aeromonas hydrophila merupakan salah satu jenis bakteri pathogen yang dapat menimbulkan penyakit pada ikan (Azhar $d k k$., 2020). Salah satu penyakit yang disebabkan oleh bakteri A. hydrophila adalah Motile Aeromonas Septicemia (MAS) (Yulianto dkk., 2013). Infeksi bakteri A. hydrophila menyebabkan $80 \%$ kematian ikan budidaya pada berbagai stadia (Tambunan $d k k .$, 2011).

Penanggulangan penyakit pada sistem budidaya dengan menggunakan antibiotik telah dilakukan untuk mengobati penyakit MAS pada ikan, akan tetapi peneliti menemukan bahwa hal ini tidak efektif dalam mengobati penyakit MAS karena mengakibatkan pencemaran lingkungan dan resistensi bakteri. Penggunaan yang tidak tepat atau penggunaan antibiotik yang berlebihan dapat meningkatkan kemungkinan munculnya strain yang kebal, terutama vaksin yang didasarkan pada antigen rekombinan atau 
patogen yang tidak aktif (Mehana et al., 2015). Selain itu, antibiotik sintesis yang terakumulasi begitu banyak dalam tubuh ikan dapat membahayakan bila dikonsumsi manusia (Pratama $d k k .$, 2017).

Indonesia sebagai salah satu negara tropis memiliki keanekaragaman hayati yang tinggi sebagai sumber bahan alami (natural product) yang berasal dari tumbuhan, hewan, dan mikroorganisme. Bahan alami tersebut selain digunakan untuk kepentingan pangan dan papan, juga dimanfaatkan sebagai bahan terapeutik. Alternatif lain yang dapat dilakukan yaitu menggunakan bioaktif senyawa alami untuk metode pengobatan yang relatif aman dan efektif untuk mengatasi masalah penyakit. Efek samping dari metode pengobatan ini lebih sedikit dari pada obat-obatan atau zat sintesis dan lebih murah (Nur $d k k ., 2018$ ).

Salah satu biota laut yang banyak terdapat di perairan Indonesia serta dapat dimanfaatkan zat aktifnya adalah golongan gastropoda. Gastropoda merupakan salah satu jenis biota laut yang dapat dimanfaatkan sebagai antibakteri karena dapat menghasilkan metabolit sekunder. Senyawa bioaktif yang dihasilkan oleh gastropoda beberapa diantaranya diteliti aktivitasnya bukan hanya sebagai antibakteri, bahkan sebagai kandidat dari sumber obatobatan baru. Penelitian tentang gastropoda telah banyak dilakukan diantaranya oleh Ashari et al., (2020) bahwa pada beberapa biota laut, contohnya pada teripang Bohadschia sp. baik untuk dimanfaatkan karena senyawa aktif yang dikandungnya pada dosis tertentu tidak bersifat toksik sehingga aman untuk digunakan. Penelitian Prem Anand $d k k$., (2010) menemukan bahwa ekstrak gastropoda laut Pleuropoca trapezium dengan menggunakan metanol memiliki aktivitas antioksidan dengan nilai $\mathrm{IC}_{50}$ sebesar $4021 \mu \mathrm{g} / \mathrm{mL}$. Ravi dkk., (2012) menyatakan ekstrak aseton dari gastropoda laut Henufusus pugilinus memiliki aktivitas anti inflamasi tertinggi pada konsentrasi $1 \mathrm{ml}$ sebesar $72.58 \pm 1.66 \%$. Selain itu, penelitian tentang pemanfaatan biota laut lainnya telah dilakukan yaitu pada teripang pasir oleh Nur $d k k$., (2019) menyebutkan bahwa teripang pasir $H$. scabra yang diambil dari perairan Atowatu, Sulawesi Tenggara mengandung bahan aktif steroid dan mampu menghambat pertumbuhan bakteri $V$. harveyi. Walaupun pada dosis tertinggi yang diujikan (10000 ppm) menunjukkan penghambatan yang lebih rendah dibandingkan antibiotik Erythromicin 10 ppm, namun ekstrak steroid ini sudah menunjukkan penghambatan pada semua dosis yang diujikan, bahkan pada dosis minimum yakni $10 \mathrm{ppm}$. Olehnya teripang pasir tersebut berpotensi untuk pengembangan industri farmasi maupun obat-obatan penyakit udang/ikan. Penelitian Azlan et al., (2021) Holuthuria scabra merupakan salah satu teripang yang memiliki senyawa aktif dan diketahui memiliki antibakteri (Arifin et al., 2013), aktivitas antijamur (Mohammadizadeh et al., 2013), dan anktivitas antioksidan (Nobsathian et al., 2017). Menurut Azlan et al., (2021), pemberian ekstrak etanol H. Scabra pada Cyprinus carpio memiliki potensi sebagai imunostimulan untuk pencegahan infeksi $A$. hydrophila.

Kelinci laut (D. auricularia) merupakan salah satu invertebrata laut yang tergolong ke dalam gastropoda dan jumlahnya cukup melimpah di perairan pantai Sulawesi Tenggara. Komponen aktif dari kelinci laut tersebut dengan nama Dolastin 10 yang mempunyai keaktifan sebagai antimitosis dan saat ini sedang dalam uji klinis tahap I sebagai obat kanker hati, kanker payudara, tumor dan leukemia (Manullang, 2016). Hewan akuatik ini diduga memiliki potensi besar dalam menghasilkan senyawa bioaktif seperti pada biota akuatik lainnya yang dapat dimanfaatkan sebagai antibakteri, khususnya untuk pengendalian penyakit MAS yang menyerang ikan air tawar.

Penelitian ini bertujuan untuk mengetahui senyawa aktif dari hasil ekstraksi kelinci laut serta mengkaji kemampuan bahan aktif dalam mengendalikan infeksi bakteri patogen $A$. hydrophila melalui pengamatan penghambatannya secara in vitro. Eksplorasi senyawa bioaktif dari organisme bahari di Indonesia terutama di wilayah Sulawesi Tenggara perlu dilakukan untuk pemanfaatan sumber daya non konvensional termasuk isolasi/ekstraksi dan identifikasi bioaktif. Kemungkinan diperoleh berbagai senyawa bioaktif dapat digunakan untuk kebutuhan farmasi maupun untuk pengendalian penyakit khususnya penyakit pada ikan yang sering menjadi permasalahan di hatchery maupun di tambak dimana kerap terjadi kematian ikan secara massal sebagai akibat serangan penyakit MAS. 


\section{BAHAN DAN METODE}

Penelitian ini terbagi menjadi beberapa tahapan yaitu pengambilan sampel, ekstraksi kelinci laut, evaporasi dan uji kandungan senyawa aktif. Penelitian ini dilakukan sebanyak 12 kali ulangan dengan lima perlakuan $\mathrm{K}^{-}$ (Phosphate Buffered Saline), $\mathrm{K}^{+}$(Kloramfenikol $30 \mathrm{ppm}), 7000,5000,2000$ dan 1000 ppm ekstrak kelinci laut dan pengamatan dilakukan setelah 24 jam inkubasi.

Ekstraksi kelinci laut dilakukan di Laboratorium Unit Kimia Analitik Jurusan Kimia Fakultas Matematika dan Ilmu Pengetahuan Alam, Universitas Halu Oleo, Kendari. Selanjutnya uji kandungan senyawa aktif ekstrak kelinci laut secara kualitatif dilakukan di Laboratorium Farmasi, Fakultas Farmasi, Universitas Halu Oleo, Kendari. Uji dilakukan pada bulan Februari-April 2021.

\section{Ekstraksi untuk Uji Kandungan Bahan Aktif}

Evaporasi sampel dan uji kandungan senyawa aktif ekstrak kelinci laut secara kualitatif dilakukan di Laboratorium Farmasi, Fakultas Farmasi, Universitas Halu Oleo, Kendari.

Ekstraksi kelinci laut dilakukan dengan metode yang dilakukan oleh Manullang (2016). Pelarut yang digunakan dalam ekstraksi kelinci laut yaitu etil asetat. Rasio bahan dan pelarut yang digunakan yaitu 1:2. Sampel daging dan jeroan kelinci laut basah dipotong kecil-kecil, kemudian diblender, lalu ditimbang untuk mengetahui berat bahan awal. Berat bahan awal basah yang digunakan yaitu $8 \mathrm{~kg} 198 \mathrm{~g}$. Setelah itu, sampel dimasukkan ke dalam toples kaca. Sampel dimaserasi dengan cara direndam dengan pelarut sebanyak 16,396 L. Kemudian sampel diaduk menggunakan shaker selama 24 jam. Larutan ekstrak yang diperolah disaring menggunakan kertas saring untuk memisahkan filtrat dan residunya. Setelah itu residu direndam kembali dengan pelarut sebanyak 16,396 L selama 24 jam dan disaring kembali untuk memisahkan fiiltrat dan residunya. Filtrat dievaporasi dengan rotary evaporator pada suhu $40^{\circ} \mathrm{C}$. Ekstrak yang diperoleh dihitung rendemennya.

\section{Skrining Kandungan Senyawa Ekstrak Secara Kualitatif}

Metode skrining kandungan senyawa secara kualitatif dilakukan dengan metode kolorimetri untuk mend eteksi keberadaan metabolit sekunder dalam ekstrak menggunakan metode standar (Yadav dan Agarwala, 2011).

\section{Uji fenol dan tanin}

Sebanyak $0,1 \mathrm{~mL}$ ekstrak dicampur dengan $2 \mathrm{~mL}$ larutan $2 \% \mathrm{FeCl}_{3}$. Pewarnaan biru kehijauan atau hitam menunjukkan adanya fenol dan tanin.

\section{Uji flavonoid}

Sebanyak $0,1 \mathrm{~mL}$ ekstrak dicampur dengan $2 \mathrm{~mL}$ larutan $2 \% \mathrm{NaOH}$. Warna kuning pekat terbentuk yang berubah menjadi tidak berwarna dengan penambahan beberapa tetes asam encer yang menunjukkan adanya flavonoid.

\section{Uji steroid dan terpenoid}

Sebanyak $0,1 \mathrm{~mL}$ ekstrak dicampur dengan $2 \mathrm{~mL}$ kloroform dan $\mathrm{H}_{2} \mathrm{SO}_{4}$ pekat serta asam asetat dituangkan ke dalam campuran. Perubahan warna dari merah menjadi biru atau kehijauan menunjukkan adanya steroid dan terpenoid.

\section{Uji alkaloid}

Sebanyak $0,1 \mathrm{~mL}$ ekstrak kasar dicampur dengan $2 \mathrm{~mL} \mathrm{HCl} \mathrm{1 \%} \mathrm{dan} \mathrm{dipanaskan} \mathrm{perlahan.}$ Reagen Mayer kemudian ditambahkan ke dalam campuran. Kekeruhan dari endapan yang dihasilkan diambil sebagai bukti adanya alkaloid.

\section{Uji saponin}

Sebanyak 0,1 mL ekstrak kasar dicampur dengan $5 \mathrm{~mL}$ akuades dalam tabung reaksi dan dikocok kuat-kuat. Pembentukan busa yang stabil diambil sebagai indikasi adanya saponin.

\section{Ekstraksi untuk Uji Daya Hambat (In Vitro)}

Kelinci laut dibersihkan isi dalamnya kemudian dicuci bersih. Kelinci laut yang sudah dicuci bersih kemudian dijemur dibawah matahari atau dikeringkan dengan menggunakan oven pada suhu $40-50^{\circ} \mathrm{C}$, sampai kadar airnya hilang kemudian diiris tipis-tipis. Bahan yang sudah diiris tipis kemudian dihaluskan sampai berbentuk serbuk halus kemudian disaring menggunakan tirisan untuk memisahkan serbuk halus dan kasar. Setelah ditiriskan bahan baku siap untuk diekstraksi.

Proses ekstraksi kelinci laut dilakukan dengan metode maserasi dengan cara merendamkan serbuk halus kelinci laut yang telah ditiriskan dengan pelarut etanol 96\% 
sebanyak $100 \mathrm{ml}$ selama \pm 24 jam dan kemudian disaring menggunakan kertas saring untuk memisahkan antara filtrat dan residunya. Residu yang sudah dipisahkan kemudian direndam kembali dengan pelarut etanol sebanyak $100 \mathrm{ml}$ selama 24 jam dan disaring menggunakan kertas saring. Pelarut etanol diuapkan dengan menggunakan Rotary Evaporator pada suhu $40^{\circ}$ dan kemudian diperoleh ekstrak kental yang disebut dengan ekstrak kelinci laut.

\section{Uji Penghambatan Tumbuh Bakteri}

Uji daya hambat bakteri dilakukan selama 2 minggu pada bulan Januari 2018 di Laboratorium Kesehatan Ikan Fakultas Perikanan dan Ilmu Kelautan Universitas Halu Oleo, Kendari.

Uji kemampuan antibakteri dari hasil ekstraksi kelinci laut dilakukan dengan uji penghambatan dengan metode kertas cakram Kirby-Bauer. Cawan petri yang berisi media TSA diambil sebanyak tiga buah. Masingmasing cawan diberikan label konsentrasi ekstrak $\left(\mathrm{K}^{-}, \mathrm{K}^{+}, 7000,5000,2000\right.$ dan 1000 $\mathrm{ppm})$. Selanjutnya menyiapkan lampu bunsen, alkohol $70 \%$, mikro pipet, kertas saring, ekstrak kelinci laut masing-masing konsentrasi. $\mathrm{K}^{+}$ adalah antibiotik Kloramfenikol $30 \mathrm{ppm}$ sedangkan $\mathrm{K}^{-}$adalah larutan Phosphate Buffered Saline (PBS) yang masing-masing sudah dimasukkan dalam botol film sebanyak $3 \mathrm{ml}$. Kertas saring yang sudah disterilkan dimasukan kedalam botol film selama \pm 5 menit. Bakteri yang telah diencerkan diambil sebanyak $0,5 \mathrm{ml}$ menggunakan mikro pipet kemudian diteteskan dalam cawan petri yang berisi media TSA. Bakteri yang sudah diteteskan dalam cawan kemudian diratakan menggunakan batang penyebar, selanjutnya mengambil kertas saring yang sudah direndam dalam ekstrak terlebih dahulu dan diletakkan dalam cawan petri pada masing-masing label konsentrasi. Selanjutnya dibungkus menggunakan plastik rol dan kertas. Kemudian dimasukkan dalam inkubator selama 24 jam pada suhu $35^{\circ} \mathrm{C}$. Zona bebas bakteri di sekeliling kertas cakram yang kelihatan bening dan luas daerah hambatannya diukur. Perlakuan dilakukan sebanyak 3 kali dengan metode yang sama.

\section{Analisis Data}

Zona hambat dari ekstrak kelinci laut dianalisis secara deskriptif dengan membandingkan diameter zona hambat antar perlakuan.

\section{HASIL}

\section{Rendemen Ekstrak Kelinci Laut}

Rendemen ekstrak kelinci laut dapat dilihat pada Tabel 1.

Tabel 1. Rendemen Ekstrak Kelinci Laut

\begin{tabular}{cccc}
$\begin{array}{c}\text { Nama } \\
\text { Pelarut }\end{array}$ & $\begin{array}{c}\text { Berat } \\
\text { Ekstrak } \\
(\mathrm{g})\end{array}$ & $\begin{array}{c}\text { Berat Bahan } \\
\text { Awal } \\
(\text { Basah })(\mathrm{g})\end{array}$ & $\begin{array}{c}\text { Rendemen } \\
\text { Ekstrak } \\
(\%)\end{array}$ \\
\hline $\begin{array}{c}\text { Etil } \\
\text { Asetat }\end{array}$ & 26,24 & 8,198 & 0,32 \\
\hline
\end{tabular}

Uji Kandungan Senyawa Ekstrak Kelinci Laut Secara Kualitatif

Hasil uji kandungan senyawa ekstrak kelinci laut secara kualitatif dapat dilihat pada Tabel 2.

Tabel 2. Kandungan Senyawa Ekstrak Secara Kualitatif

\begin{tabular}{|c|c|c|c|}
\hline \multicolumn{4}{|c|}{ Senyawa } \\
\hline $\begin{array}{l}\text { Phenolic } \\
\text { dan } \\
\text { Tanin } \\
\end{array}$ & Flavonoid & $\begin{array}{l}\text { Steroid } \\
\text { dan } \\
\text { Terpenoid } \\
\end{array}$ & Alkaloid Saponins \\
\hline+ & - & + & + \\
\hline
\end{tabular}

Keterangan : $(+)=$ Terdeteksi; $(-)=$ Tidak Terdeteksi

\section{Pengujian Penghambatan Ekstrak Kelinci Laut terhadap Bakteri $A$. hydrophila}

Hasil pengujian penghambatan ekstrak terhadap bakteri dapat dilihat pada Tabel 3.

Tabel 3. Rata-Rata Daya Hambat Bakteri $A$. hydrophila Pada Berbagai Dosis Ekstrak Kelinci Laut

\begin{tabular}{|c|c|c|}
\hline Dosis (ppm) & $\begin{array}{l}\text { Rata-rata } \\
\text { Daya Hambat } \\
\text { Bakteri }(\mathrm{cm})\end{array}$ & $\begin{array}{l}\text { Interpretasi } \\
\text { Daya } \\
\text { Hambat }\end{array}$ \\
\hline 7000 & $0.614 \pm 0.323$ & Resistant \\
\hline 5000 & $0.612 \pm 0.388$ & Resistant \\
\hline 2000 & $0.433 \pm 0.186$ & Resistant \\
\hline $\begin{array}{l}1000 \\
\mathrm{~K}^{-}(\mathrm{PBS})\end{array}$ & $\begin{array}{l}0.250 \pm 0.070 \\
0.000\end{array}$ & Resistant \\
\hline $\begin{array}{l}\mathrm{K}^{+} \\
\text {(Kloramfenikol) } \\
30\end{array}$ & $1.133 \pm 1.146$ & Resistant \\
\hline $\begin{array}{l}\text { Masing-masing } \\
\text { dosis }\end{array}$ & $\mathrm{n}=12$ & \\
\hline $\begin{array}{l}\text { Keterangan : } \\
\text { Interpretasi daya } 1 \\
\text { Resistant; 15-18 } \\
\text { Susceptible }\end{array}$ & $\begin{array}{l}\text { bat (CLSI, } \\
=\text { Interme }\end{array}$ & $\begin{array}{l}: \leq 14 \mathrm{~mm}= \\
\geq 19 \mathrm{~mm}=\end{array}$ \\
\hline
\end{tabular}




\section{PEMBAHASAN}

Salah satu yang menjadi parameter mutu ekstrak yaitu rendemen, semakin tinggi nilai rendemen yang dihasilkan menandakan ekstrak yang dihasilkan akan semakin banyak. Hasil pengukuran rendemen ekstrak kelinci laut menggunakan pelarut etil asetat yang diperoleh tergolong rendah yaitu $0,32 \%$ jika dibandingkan dengan hasil pengukuran rendemen ekstrak kelinci laut menggunakan pelarut etil asetat dalam penelitian Manullang (2016) yaitu 1,34\%. Hal ini dipengaruhi oleh suhu, jenis pelarut, perbandingan bahan dan pelarut, waktu dalam melakukan ekstraksi, serta ukuran partikel (Chairunnisa $d k k$., 2019). Selain itu, hal ini juga diduga karena senyawa metabolit sekunder kelinci laut banyak menggandung senyawa yang bersifat polar. Sehingga rendemen juga dapat menandakan banyak atau sedikitnya komponen aktif yang berhasil terekstraksi. Hal ini sesuai dengan Zuraida $d k k$., (2017) bahwa rendemen menunjukan komponen aktif yang berhasil terekstraski. Menurut Supiyanti $d k k$., (2010) tingginya rendemen yang terdapat pada pelarut menunjukkan pelarut tersebut mampu mengekstrak lebih banyak komponen bioaktif yang memiliki sifat kepolaran yang lebih tinggi. Hal ini diduga karena komponen bunga lotus banyak mengandung senyawa polar. Menurut Romadanu $d k k$. , (2014) perbedaan jenis pelarut mempengaruhi jumlah ekstrak yang dihasilkan. Menurut Wijaya dkk., (2018) bahwa rendemen ekstrak yang dihasilkan merupakan salah satu parameter mutu ekstrak, semakin tinggi nilai rendemen menandakan nilai ekstrak yang dihasilkan semakin banyak. Rendemen suatu ekstrak dapat dipengaruhi oleh beberapa faktor salah satunya adalah metode ekstrak yang digunakan. Ekstraksi menggunakan pelarut terdiri dari cara dingin salah satunya maserasi. Ditinjau dari segi waktu, untuk memperoleh zat aktif yang lebih banyak dibutuhkan waktu dan proses yang lama karena ekstraksi ini tidak menggunakan bantuan panas. Namun dari segi suhu, metode ini merupakan ekstraksi cara dingin yang dilakukan dalam suhu ruang dan relatif aman digunakan untuk bahan-bahan yang tahan atau tidak tahan terhadap pemanasan. Istiqomah (2013), menyatakan bahwa sebagian besar senyawa dapat terekstraksi dengan ekstraksi cara dingin.

Hasil uji kandungan senyawa ekstrak kelinci laut secara kualitatif terdeteksi menggandung senyawa steroid, terpenoid, alkaloid, tanin, phenolic dan saponin. Etil asetat merupakan pelarut yang bersifat semi polar sehingga mampu menarik senyawa yang bersifat polar maupun semi polar. Senyawa yang bersifat polar yaitu alkaloid, tanin, phenolic, dan saponin. Sedangkan steroid bersifat non polar sampai semi polar dan terpenoid bersifat semi polar. Senyawa alkaloid, saponin, dan tanin dapat ditarik oleh fraksi etil asetat disebabkan oleh adanya elektron yang beresonansi pada cincin benzena yang mengakibatkan kepolaran senyawa tersebut berkurang sehingga lebih tertarik oleh etil asetat yang bersifat semipolar. Selain itu, adanya ikatan hidrogen meningkatkan interaksi senyawa tersebut pada etil asetat. Hal ini sesuai dengan penelitian Nurjanah et al., (2011) yang menyatakan bahwa steroid biasanya terdapat pada pelarut yang bersifat non polar dan semi polar. Menurut Verdiana $d k k$., (2018) bahwa aseton merupakan pelarut semi polar yang dapat menarik senyawa polar dan semi polar.

Perbedaan hasil ekstraksi yang diperoleh menurut Putri $d k k$., (2012) bahwa senyawa atau komponen metabolit sekunder dapat berasal dari makanan yang dikonsumsi oleh organisme. Senyawa alkaloid merupakan substansi organik yang tidak bersifat vital bagi organisme yang menghasilkannya, tetapi tidak menutup kemungkinan bahwa komponen alkaloid ini berasal dari makanan yang dikonsumsi oleh organisme. Kelinci laut menyukai alga hijau jenis Cladophora, lamun jenis Cymodocea rotundata serta jenis alga coklat Sargassum cristaefolium. Dalam penelitian Bintari dan Elyani, (2017) menyatakan bahwa ekstrak Cladophora sp. menggandung alkaloid. Menurut Gazali dkk., (2018) menyatakan bahwa ekstrak etanol dan n-heksan Sargassum sp. menggandung senyawa alkaloid dan fenol. Menurut Gustavina $d k k$., (2018) menyatakan bahwa berdasarkan hasil uji kandungan senyawa fitokimia pada akar lamun akar Cymodocea rotundata terbukti menggandung senyawa alkaloid. Widarta et al., (2013) menyebutkan perbedaan jenis dan tingkat kepolaran pelarut dapat menghasilkan rendemen ekstrak dan komponen bioaktif yang berbeda. Sompong et al., (2011) menyatakan bahwa perbedaan spesies dan tempat tumbuh menghasilkan komponen bioaktif yang berbeda.

Berdasarkan hasil uji in vitro untuk melihat zona hambat dari ekstrak kelinci laut 
dengan mengukur tingkat penghambatannya terhadap bakteri $A$. hydrophila, tampak bahwa ektrak kelinci laut tersebut memiliki potensi untuk menghambat pertumbuhan A. hydrophila. Hal tersebut dapat dilihat dari zona hambat bebas bakteri yang terbentuk (clear zone) disekitar kertas cakram yang mengandung bahan ekstrak kelinci laut. Berdasarkan analisa secara deskriptif menunjukkan bahwa variasi dosis ekstrak kelinci laut memberikan perbedaan pada rata-rata daya hambat bakteri $A$. hydrophilla. Pada hasil penelitian Nur, $d k k$., (2019) menyimpulkan bahwa pada ekstraksi organisme laut jenis teripang pasir Holothuria scabra yang ditemukan juga mengandung bahan aktif steroid dan secara in vitro mampu menghambat pertumbuhan bakteri Vibrio harveyi. Selanjutnya pada uji in vivo pada ikan mas secara perendaman, menunjukkan bahwa bahan aktif yang ada pada teripang pasir menyebabkan profil darah lebih baik dan berpotensi juga sebagai imunostimulan (Azlan et al., 2021).

Interpretasi daya hambat untuk semua dosis pada penelitian ini menunjukan hasil yang sama yaitu resistant atau rendah. Hal ini sesuai dengan CLSI (2013) bahwa interpretasi dengan kategori resistant yaitu $\leq 14 \mathrm{~mm}$. Namun jika dilihat dari kemampuan penghambatan ekstrak terhadap bakteri masih rendah bila dibandingkan antibiotik. Sebagai kontrol positif, penelitian ini menggunakan antibiotik Kloram fenikol 30 ppm. Kemampuan antibakterial yang cenderung jauh lebih rendah dari antibiotik yang dihasilkan dalam penelitian ini memiliki kesamaan dengan penelitian yang dilakukan oleh Villasine (2000) yang menggunakan ekstrak teripang Parastichopus parvimensis. Zona hambat yang ditunjukkan oleh bahan aktif dari ekstrak tersebut juga masih rendah dibandingkan antibiotik ampicillin dan tetracyclin. Dari hasil penelitian pada dosis tertinggi yang diujikan (7000 ppm) menunjukkan penghambatan yang lebih rendah dibandingkan antibiotik Kloramfenikol 30 ppm, namun ekstrak kelinci laut ini sudah menunjukkan penghambatan pada semua dosis yang diujikan, bahkan pada dosis minimum yakni 1000 ppm. Dengan demikian dapat dikatakan bahwa kelinci laut berpotensi untuk pengembangan obat-obatan penyakit ikan pada akuakultur.

\section{KESIMPULAN}

Kelinci laut D. auricularia yang diambil dari perairan Kabupaten Konawe mengandung bahan aktif senyawa steroid, terpenoid, alkaloid, tanin, phenolic dan saponin, serta mampu menghambat pertumbuhan bakteri $A$. Hydrophilla bahkan pada dosis minimum yakni $1000 \mathrm{ppm}$.

\section{REFERENSI}

Arifin, H.N., Ningsih, R., Fitrianingsih, A.A., Hakim, A. (2013). Antibacterial Activity Test Sea Cucumber Extract (Holothuria scabra) Sidayu Coast Gresik Using Disk Diffusion Methode. Alchemy, 2(2), 101106.

DOI: https://doi.org/10.18860/al.v0i0.2882

Ashari, L.O.H., Nur, I., Haslianti. (2020). Toxicity Test of Sea Cucumber Bohadschia sp Extract from the South East Sulawesi Coastal Waters Indonesia Against Carp Fish (Cyprinus carpio Linn). International Journal of Zoology and Animal Biology, 4(2), 000282.

Azhar, F., Junaidi, M., Muklis, A., Scabra, A. R. (2020). Penanggulangan Penyakit MAS (Motile Aeromonas Septicemia) pada Ikan Nila Menggunakan Ekstrak Temulawak (Curcuma xanthorriza Roxb). Jurnal Abdi Insani Universitas Mataram, 7(3), 320-324. DOI: https://doi.org/10.29303/abdiinsani.v7i3 .282

Azlan, Nur, I., Abidin, L.O.B. (2021). Active Compounds and Immunostimulating Potential of Holothuria scabra Extract in Common Carp Fish (Cyprinus carpio) Against Aeromonas hydrophila Infection. International Journal of Zoology and Animal Biology, 4(1), 000271.

Bintari,Y.R., Elyani, H. (2017). Ekstraksi Senyawa Bioaktif dari Cladophora sp. dengan Metode Solvent Free Microwave Extraction (SFME). Journal of Islamic Medicini Research, 1(1), 1-11.

Chairunnisa, S., Wartini, N.M., Suhendra, L. (2019). Pengaruh Suhu dan Waktu Maserasi terhadap Karakteristik Ekstrak Daun Bidara (Ziziphus mauritiana L.) sebagai Sumber Saponin. Jurnal Rekayasa dan Manajemen Agroindustri, 7(4), 551-560. 
Clinical Laboratory Standart Institute. (2013). Performance Standart of Antimicrobial Susceptibility Testing; Twentieth Information Supplement. USA.

Gazali, M., Nurjanah, N., \& Zamani, N. P. (2018). Eksplorasi senyawa bioaktif alga cokelat Sargassum sp. Agardh sebagai antioksidan dari Pesisir Barat Aceh. Jurnal Pengolahan Hasil Perikanan Indonesia, 21(1), 167-178. DOI: https://doi.org/10.17844/jphpi.v21i1.21 543

Gustavina, N.L.G.W.B., Dharma, I.G.B.S., Faiqoh, E. (2018). Identifikasi Kandungan Senyawa Fitokimia pada Daun dan Akar Lamun di Pantai Semuh Bali. Journal of Marine and Aquatic Sciences, 4(2), 271-277.

Istiqomah. (2013). Perbandingan Metode Ekstraksi Maserasi dan Sokletasi terhadap Kadar Piperin Buah Cabe Jawa (Piperis retrofracti fructus). Skripsi. Universitas Islam Negeri Syarif Hidayatullah. Jakarta.

Manullang, B., (2016). Aktivitas Ekstrak Kelinci Laut (Dolabella auricularia) sebagai Inhibitor $\alpha$-glukosidase, Stabilisator Sel Darah Merah, Antibakteri dan Antioksidan. Tesis. Sekolah Pascasarjana. Institut Pertanian Bogor. Bogor.

Mehana, E. E., Rahmani, A. H., \& Aly, S. M. (2015). Immunostimulants and fish culture: an overview. Annual Research \& Review in Biology, 477-489. DOI: https://doi.org/10.9734/ARRB/2015/955 8

Mohammadizadeh, F., Ehsanpor, M., Afkhami, M., Mokhlesi, A., Khazaali, A., \& Montazeri, S. (2013). Evaluation of antibacterial, antifungal and cytotoxic effects of Holothuria scabra from the north coast of the Persian Gulf. Journal de mycologie médicale, 23(4), 225-229. DOI: https://doi.org/10.1016/j.mycmed.2013. 08.002

Nobsathian, S., Tuchinda. P., Sobhon. P., Tinikul, Y., Poljaroen, J. (2017). An Antioxidant Activity of the Whole Body of Holothuria scabra. Chemical Biological Technologies in Agriculture, 4(4), 1-5.
Nur, I., Asnani, Ma'ruf, K. (2018). Pengaruh Suplementasi Kitin dari Kulit Udang terhadap Profil Darah Ikan Mas (Cyprinus carpio). Jurnal Sains dan Inovasi Perikanan, 2(2), 69-75. DOI: http://dx.doi.org/10.33772/jsipi.v2i2.75 76

Nur, I., Santi, Kurnia, A. (2019). Efficacy of Guava (Psidium guajava) Leaves Extract to Prevent Vibriosis in White Shrimp (Litopenaeus vannamei). Research Journal of Medicinal Plants, 13(4), 136-144. DOI: https://doi.org/10.3923/rjmp.2019.136.1 44

Nur, I., Asnani, Yusnaini. (2019). Potensi Ekstrak Steroid dari Teripang Pasir Holothuria scabra dari Perairan Atowatu Kendari untuk Pengendalian Bakteri Vibrio harveyi. Jurnal Sains dan Inovasi Perikanan, 3(1), 26-31. DOI: http://dx.doi.org/10.33772/jsipi.v3i1.75 68

Nurjanah, N., Izzati, L., \& Abdullah, A. (2011). Aktivitas antioksidan dan komponen bioaktif kerang pisau (Solen spp). ILMU KELAUTAN: Indonesian Journal of Marine Sciences, 16(3), 119-124. DOI: https://doi.org/10.14710/ik.ijms.16.3.11 9-124

Pratama,R.C., Rosidah, Sriati, Rustikawati, I. (2017). Efektivitas Ekstrak Biji Rambutan dalam Mengobati Benih Ikan Mas yang Terinfeksi Bakteri Aeromonas hydrophila. Jurnal Perikanan dan Kelautan, 8(1), 130-138.

Prem Anand, T., Chellaram, C., Kumaran, S., \& Felicia Shanthini, C. (2010). Biochemical composition and antioxidant activity of Pleuroploca trapezium meat. Journal of Chemical Pharmaceutical Research, 2(4), 526-535.

Putri, M. K. D., Pringgenies, D., \& Radjasa, O. K. (2012). Uji fitokimia dan toksisitas ekstrak kasar gastropoda (Telescopium telescopium) terhadap larva Artemia salina. Journal of Marine Research, 1(2), 58-66.

DOI: https://doi.org/10.14710/jmr.v1i2.2020

Ravi, C., Karthiga, A., Venkatesan, V. (2012). Isolation and Biomedical Screening of the Tissue Extracts of Two Marine Gastropods Hemifusus pugilinus (Born. 
1778) and Natica didyma (Roding. 1798). Journal Asian Fisheries Science, $25,158-169$.

Romadanu, R., Hanggita, S., \& Lestari, S. D. (2014). Pengujian aktivitas antioksidan ekstrak bunga lotus (Nelumbo nucifera). Jurnal FishtecH, 3(1), 1-7. DOI: https://doi.org/10.36706/fishtech.v3i1.3 523

Supiyanti, W., Wulansari, E.D., Kusmita, L. (2010). Uji Aktivitas Antioksidan dan Penentuan Kandungan Antosianin Total Kulit Buah Manggis (Garcinia mangostana L.). Farmasi, 15(2), 64-70.

Sompong, R., Siebenhandl-Ehn, S., LinsbergerMartin, G., \& Berghofer, E. (2011). Physicochemical and antioxidative properties of red and black rice varieties from Thailand, China and Sri Lanka. Food chemistry, 124(1), 132-140. DOI: https://doi.org/10.1016/j.foodchem.201 0.05 .115

Tambunan, J.E., Mahasri, G., Setiawan, K. (2011). Infestasi Ektoparasit Lernaea Sebagai Faktor Pemicu Munculnya Infeksi Bakteri Aeromonas pada Benih Ikan Mas (Cyprinus carpio L.). Skripsi. Fakultas Perikanan dan Kelautan Universitas Airlangga. Surabaya.

Verdiana, M., Widarta, I. W. R., \& Permana, I. D. G. M. (2018). Pengaruh jenis pelarut pada ekstraksi menggunakan gelombang ultrasonik terhadap aktivitas antioksidan ekstrak kulit buah lemon (Citrus limon (Linn.) Burm F.). Jurnal Ilmu dan Teknologi Pangan (ITEPA), 7(4), 213222.

Widarta, I. W. R., Nocianitri, K. A., \& Sari, L. P. I. P. (2013). Ekstraksi komponen bioaktif bekatul beras lokal dengan beberapa jenis pelarut. Jurnal Aplikasi Teknologi Pangan, 2(2), 75-79.

Wijaya, H., Novitasari, J. S., \& Jubaidah, S. (2018). Perbandingan metode ekstraksi terhadap rendemen ekstrak daun rambai laut (Sonneratia caseolaris L. Engl). Jurnal Ilmiah Manuntung, 4(1), 79-83.

Yadav, R.N.S., Agarwala M. (2011). Phytochemical analysis of some medicinal plants. Journal of Phytology. 3(12), 10-14.
Yulianto, R., Adiputra, Y.T., Wardiyanto, Setyawan, A. (2013). Perubahan Jaringan Organ Ikan Komet (Carassius auratus) yang di Infeksi dengan Aeromonas hydrophila. Jurnal Rekayasa dan Teknologi Budidaya Perairan, 2(1), 197-204.

Zuraida, Z., Sulistiyani, S., Sajuthi, D., \& Suparto, I. H. (2017). Fenol, flavonoid, dan aktivitas antioksidan pada ekstrak kulit batang pulai (Alstonia scholaris R. Br). Jurnal Penelitian Hasil Hutan, 35(3), 211-219.

DOI: https://doi.org/10.20886/jphh.2017.35.3 .211-219 